\title{
Role of Infection in Cot Deaths
}

\section{J. M. JOHNSTONE,* M.D., M.C.PATH ; H. S. LAWY,* DIP.BACT., M.C.PATH.}

Brit. med. F., 1966, 1, 706-709

"Cot deaths" are estimated to account for over $20 \%$ of the mortality in the age group concerned, more than 1,400 such fatalities having occurred in England and Wales in 1955 (Banks, 1958). The infants are found unexpectedly dead in the cot, having been placed there, generally the previous night, either well or suffering from an apparently trivial upset that usually had given no cause for alarm to the parents or to the medical attendant.

Earlier explanations for these deaths, such as smothering, overlaying, inhalation of vomitus, or status lymphaticus, are now seldom considered either adequate or accurate. In recent years a variety of other possible explanations have been suggested, and much of the current thought on the problem is well reviewed by Huntington and Jarzynka (1962).

There is considerable evidence that cot deaths are due to infection of the respiratory tract (Werne and Garrow, 1953; Coe and Hartman, 1960) in spite of the fact that bacteriological studies, not always very detailed, have been disappointing and pathogens have been isolated from the lungs in only a small proportion of the cases examined. Attempts to isolate a virus from the lungs have been uniformly unsuccessful.

Parish et al. (1960a, 1960b) suggested that death is due to the aspiration, during sleep, of tiny amounts of regurgitated milk feeds by infants who have become sensitized to cows' milk protein. In support of this they reported a higher mean serum titre of antibody to cows' milk protein in these infants than in live children of the same age, but this finding has not been confirmed.

The results of the present study of cot deaths are believed to support fulminating bacterial infection of the lower respiratory tract as a cause of death in a high proportion of the infants.

\section{Materials and Methods}

The study extended over the four-year period 1961-64 and is based on 56 children found dead unexpectedly in a cot, bed, or pram and in whom there was no apparent cause of death. Other children who died in similar circumstances but who had definite pathological changes, such as purulent bronchitis, bronchopneumonia, congenital heart disease, fibroelastosis of the heart, etc., were excluded from the study. A further group of 12 infants who were actually observed to die unexpectedly were also examined and are described as "observed deaths" in this paper. Another group of six children who died very rapidly or instantaneously were examined as control subjects.

Whenever possible a detailed history was taken from the parents by a coroner's officer. It is appreciated that information gained in this way is not always entirely accurate or adequate (Emery and Crowley, 1956), and sometimes an experienced coroner's officer was not available.

In each instance a detailed post-mortem examination was made, with minimum handling of the lungs before fixation, and tissue from the major viscera was examined histologically. Swabs were taken, with special care to avoid contamination, from the larynx, main bronchi, lower lobe of the lung, stomach, and middle ear. Within two hours of collection they were cultured on various media and incubated aerobically, anaerobically. and under $10 \% \mathrm{CO}_{2}$ atmosphere. When indicated

- From the Department of Pathology, Geperal Hospital, Grimsby, Lincs. virulence tests or examination for evidence of homologous agglutination were carried out. Antibiotic sensitivity of pathogenic staphylococci only was determined, three highly resistant strains being also phage-typed.

For virus studies a piece of the left lower lobe of the lung was taken and stored in virus transport medium at $-20^{\circ} \mathrm{C}$. and subsequently dispatched at the same temperature for virus culture.

Blood was taken at post-mortem examination and, as controls, from cord samples and from hospital patients by venepuncture, the serum being stored immediately at $-20^{\circ} \mathrm{C}$.

\section{Milk Protein Antibody}

Antigen. $-2 \% \mathrm{w} / \mathrm{v}$ reconstituted National dried milk powder (Gunther et al., 1960).

Antisera.-5 $\mathrm{ml}$. of the above soluble protein was given intraperitoneally each week for three weeks to two young rabbits, which were bled after a further three weeks. The sera (titre $1 / 600$ and 1/1200) were checked with sera of known high and low milk antibody titre, which were kindly supplied by Dr. R. R. A. Coombs, of the Department of Pathology, University of Cambridge. After pooling, the serum was divided into small aliquots and stored at $-20^{\circ} \mathrm{C}$.

Test.-The sensitized tanned red-cell agglutination technique of Boyden (1951), as modified by Gunther et al. (1960), was used.

The pattern was read over a concave mirror by reflected light. Only a clearly defined pattern was accepted as positive, attempts to read degrees of clumping being found to be unreliable. The use of M.R.C. tiles instead of tubes was unsatisfactory and a trial of various gel-diffusion techniques for quantitative estimation was unsuccessful.

\section{Results : Cot Deaths}

Sex and Age.-There was an excess of male children in the series (36 male, 20 female). The age at death ranged from 4 days to 2 years, the majority (42) of the deaths occurring at 1 to 5 months (Table I). In the 46 cases where the type of feeding is definitely known all but two were fed on dried cows' milk. The two exceptions were aged 4 and 8 days.

TABLE I.-Numbers of Infants in Each Age Group at Time of Death

\begin{tabular}{c|c|c|c|c|c|c|c|c|c|c}
\hline Age (in months): & $<1$ & $1-$ & $2-$ & $3-$ & $4-$ & $5-$ & $6-$ & $7-9$ & $10-$ & $13-$ \\
\hline $\begin{array}{c}\text { Cot deaths } \\
\text { Observed deaths .. }\end{array}$ & 1 & 13 & 9 & 9 & 7 & 4 & 1 & 3 & 4 & 3 \\
\hline
\end{tabular}

Time of Death.-Deaths were infrequent in the summer months and were commonest in the winter (Table II), when they were often noted to coincide with local outbreaks of respiratory-tract infection.

TABLE II.-Numbers of Iriants Dying in Each Two-month Period

\begin{tabular}{|c|c|c|c|c|c|c|c|}
\hline & & $\begin{array}{l}\text { Jan.I } \\
\text { Feb. }\end{array}$ & $\begin{array}{c}\text { March/ } \\
\text { April }\end{array}$ & $\begin{array}{l}\text { May/ } \\
\text { June }\end{array}$ & $\begin{array}{l}\text { Julyl } \\
\text { Aug. }\end{array}$ & $\begin{array}{l}\text { Sept.I } \\
\text { Oct. }\end{array}$ & $\begin{array}{l}\text { Nov.l } \\
\text { Dec. }\end{array}$ \\
\hline $\begin{array}{l}\text { Oot deaths } \\
\text { Observed deaths }\end{array}$ &  & $\begin{array}{r}10 \\
3\end{array}$ & $\begin{array}{r}12 \\
2\end{array}$ & $\begin{array}{l}8 \\
1\end{array}$ & $\begin{array}{l}2 \\
1\end{array}$ & $\begin{array}{r}10 \\
2\end{array}$ & $\begin{array}{r}14 \\
3\end{array}$ \\
\hline
\end{tabular}


Post-mortem Appearances.-The infants were usually well nourished and often overweight, with pallor about the mouth or of the face; frothy white material about the nares was occasionally present. Petechiae and haemorrhages, often very numerous, were almost invariably present in the thymus, pleurae, pericardium, and endocardium. The lungs were congested, with areas of partial and frequently extensive collapse. Moderate enlargement of the mesenteric lymph nodes was common.

Histological Appearances.-The principal changes were in the lungs, where, in addition to marked acute congestion, there were, in varying degrees and proportions, areas of partial collapse, intra-alveolar exudation, compensatory emphysema, and sometimes haemorrhage. The alveolar ducts were usually distended. In some instances the alveolar walls were thickened by oedema and mononuclear cells, and small to moderate numbers of macrophages were observed in some of the alveoli. Generally the bronchial epithelium was intact, and occasional small groups of lymphocytes, with or without some plasma cells, were present about the bronchi. Other viscera examined were the spleen (43 cases), liver (43), kidneys (41), pancreas (37), adrenals (35), thymus (33), heart (28), thyroid (26), lymph nodes (21), and parathyroid (7). Apart from acute congestion the only changes were ectopic thymus tissue in or about the thyroid (3 cases) and renal subcapsular " rests" (1).

Bacteriology.-Bacteriological examinations were made in 55 cases, and pathogenic organisms were isolated from the lower

TABLE III.-Summary of Results of Bacteriological Examination of the Lower Respiratory Tract

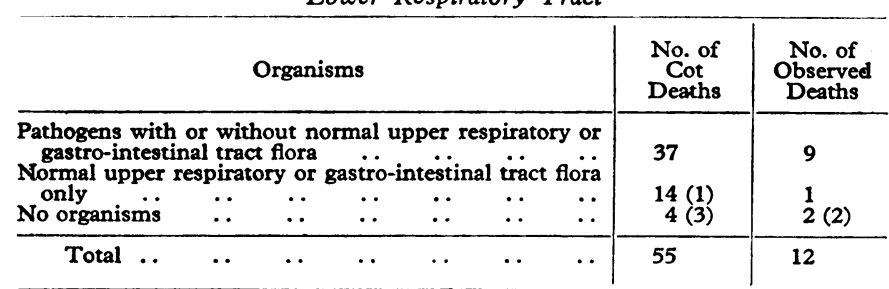

Figures in parentheses denote the number of cases in which antibiotics were given.

TABLE IV.-Types and Incidence of Pathogens Isolated from the Lower Respiratory Tract

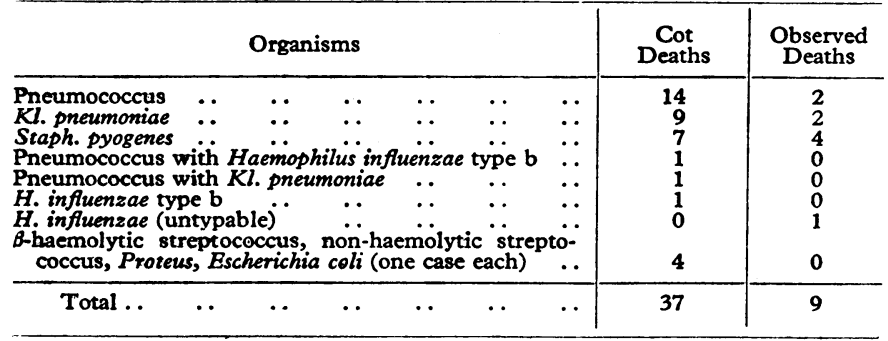

respiratory tract in 37. An outline of the bacteriological findings is given in Table III. It is of interest that in only four instances were no organisms whatsoever isolated from the lower respiratory tract and that in three of these cases an antibiotic is known to have been administered shortly before death. The types and incidence of the bacteria considered as having a pathogenic role are detailed in Table IV. The pneumococcus, alone or in combination, was the commonest pathogenic organism isolated, and was found in 16 of the necropsies. The other two common organisms were Klebsiella pneumoniae and Staphylococcus pyogenes. These three organisms were found in 32 of the 37 children in whom pathogens were isolated from the lower respiratory tract. Details of the isolation of pathogens from the various sites, in cot deaths, is shown in Table V. When found pathogens were always present in one or other of the main bronchi, usually in both, nearly always in the larynx, and in the lower lobe of the lung in more than half of the 37 infants. Pathogens were isolated from one or other middle ear in only seven instances, and in none was there macroscopical evidence of infection.

Serum Milk Protein Antibody.-The titre of serum milk protein antibody was measured in 37 cot deaths, nine observed deaths, and in a number of other infants taken as a control group (Table VI). Antibody was detected in only a small pro-

TABLE VI.-Titres of Serum Milk Protein Antibody

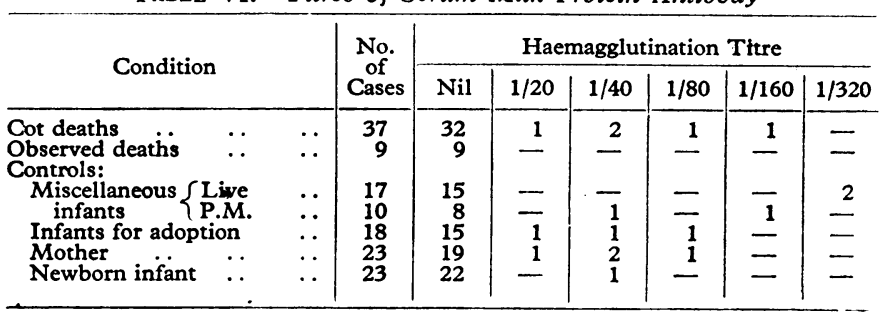

portion of the infants, and when present the titre was low in almost all cases. The percentage of cases in which milk antibody was present is virtually the same for the cot deaths as for the control group, as is the distribution of the titres.

Virology.-In 47 of the cases a part of one lower lobe of the lung was taken for virus culture on fertile hen's egg and monkey-kidney cells, but in no instance was any virus isolated.

Symptoms. - When present the symptoms were usually of an apparently trivial nature. The commonest were referable to the upper respiratory tract (34) and were mainly those of coryza at some stage of its course. Symptoms of much less frequency were irritability or crying (9), vomiting (11), and diarrhoea (7). Difficulties in feeding and pyrexia were occassianally noted.

TABLE V.-Isolation of Pathogens from Various Sites in Cot Deaths (Total Number Examined in.Parentheses).

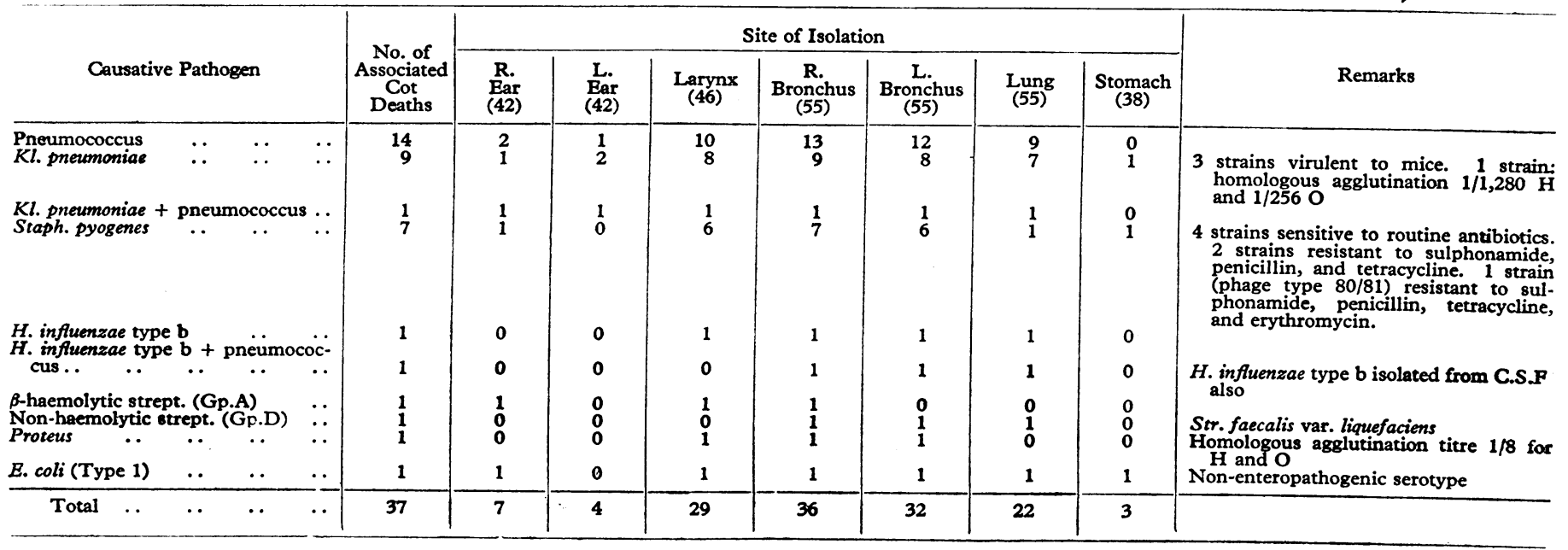




\section{Results : Observed Deaths}

In the same period other infants or children $(8$ male, 4 female) were actually observed to die in their parents' arms, in an ambulance, or on admission to hospital after a short illness with preceding trivial symptoms.

These deaths occurred most commonly in the winter (Table II) and at ages of 1 to 5 months (Table I). In the 10 instances in which the type of feeding is known it was always artificial.

The post-mortem appearances were in every way similar to those in the cot-death series. The microscopical changes in the lungs were also the same in nine infants, but fine purulent bronchiolitis was discovered in two and bronchopneumonia in one. The only change in the other viscera was the presence of venous thrombi in the kidneys of two infants.

In nine of the infants pathogens were isolated from the lung and/or main bronchi ; two of the other three infants had been given an antibiotic, and no organisms were cultured from their lungs (Table III).

Details of the isolation of pathogens from the various sites are given in Table VII. No virus was isolated from the nine lungs examined.

As in the cot-death series, the commonest symptoms were referable to the upper respiratory tract (8) and were usually tory syncytial virus of epidemic infantile bronchiolitis in infected lung tissue, and with this in mind Parish et al. (1964) collected lung material from eight cases of cot death, without freezing, but again no virus was isolated.

A new aspect on the problem of cot death was opened by Parish et al. (1960a), who reported experimental work with guinea-pigs in support of the hypothesis that the inhalation of a small quantity of regurgitated cows' milk may produce a modified anaphylactic reaction, with sudden death, in a sleeping infant sensitized to cows' milk. Further support was given (Parish et al., 1960b, 1964) by the demonstration of a higher mean titre of cows' milk antibody in the serum of infants who died suddenly (cot death) than in living infants in the same age group. This difference in the mean serum titre of milk protein antibody between cases of cot death and live infants could not be confirmed in the present series nor in the cases reported by Coe and Peterson (1963), Peterson and Good (1963), and Gold et al. (1964).

The striking feature of the present investigation is the frequency $(67 \%)$ of isolation of pathogens from the lower respiratory tract of cases of cot deaths.

Surprisingly few detailed bacteriological studies have been made of the lower respiratory tract in cot deaths, and comparison of the recorded results is difficult, as the criteria for cot

TABLe VII.-Isolation of Pathogens from Various Sites in Observed Deaths. (Total Number Examined Shown in Parentheses)

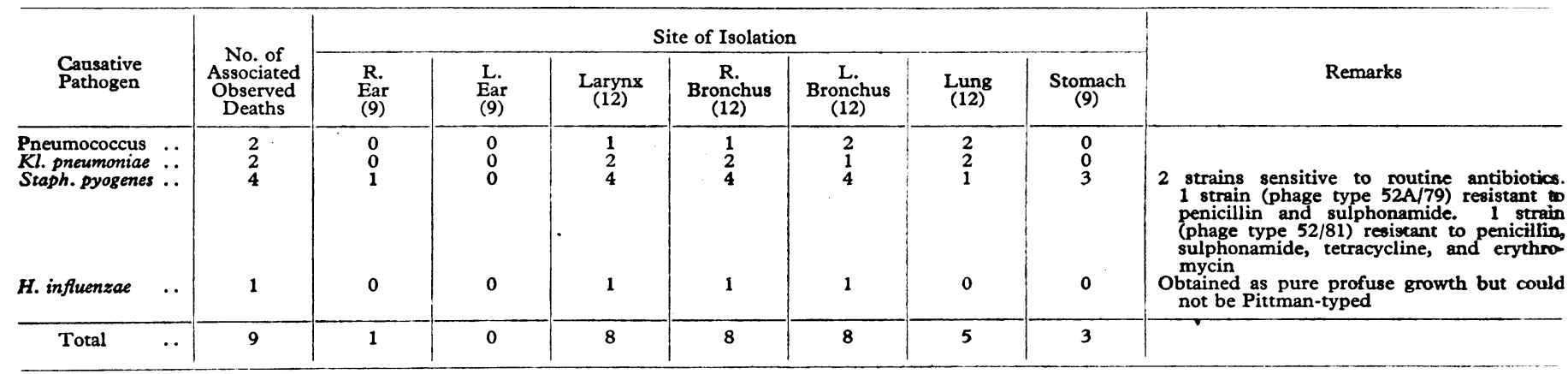

those of a recent " cold." Irritability, restlessness, and undue crying were the main features in four and diarrhoea and vomiting in three. In eight of these infants the duration of symptoms was only one to ten hours.

\section{Results : Control Cases}

Bacteriological examinations were made in six children who died suddenly from conditions clearly unassociated with infection of the respiratory tract. These included one case of hepatic haematoma and haemoperitoneum ( 3 days), two of intraalveolar pulmonary haemorrhage (17 and 21 days), two of accidental hanging (11 and 13 months), and one road accident (11 years). In the first three children the lower respiratory tract was sterile, while in the other three there were a few colonies of saprophytes such as are found in the nasopharynx.

\section{Discussion}

In the present series of cot deaths many of the results agree with those reported by previous authors. A preponderance of male infants has been noted previously, and it is well known that the majority of the infants die before the sixth month of life, that deaths are more common in the winter months, and that often there is a history of a recent infection of the upper respiratory tract (Banks, 1958; Stowens, 1958; Coe and Hartman, 1960).

Virus studies have been attempted by the same workers, but, as in the present series, the results have been entirely negative. Recent work has shown that freezing may destroy the respira- death vary. Some workers include all children found dead unexpectedly even if an adequate pathological cause of death is found, while others include children whose death was actually observed. The sites used for bacteriological examination vary and pathogens appear to be recorded sometimes even when isolated from sites other than the lower respiratory tract.

Werne and Garrow (1953) isolated Staph. aureus (11 cases) and Str. haemolyticus ( 3 cases) from the organs of the 24 children examined, the tracheobronchial tree and the mastoid being the usual sites of recovery. Stowens (1957) reported the isolation of pathogens (Staph. aureus) from the lung or heart blood of 7 out of 116 cases, having excluded from his series all cases with prior symptoms of a possible infection of the upper respiratory or gastro-intestinal tract but including 36 in whom a specific cause of death was found. Similarly, Coe and Hartman (1960), examining the lungs and/or blood of 19 cases, found pathogens in only three, bronchopneumonia being present in two of the three. In the series reported by Banks (1958) infants in whom a specific cause of death was found were included. Pathogenic organisms were isolated from the lung areas of only 5 of the 66 infants examined bacteriologically, and Staph. albus, which he regards as a potential pathogen, was grown from a further four (Table VIII).

For the purpose of this investigation an organism was accepted as having a pathogenic role only if it was a known pathogen isolated as a pure or predominant growth from the main bronchi or lung or both, or if it was a known potential pathogen isolated as above and accom-a-iied by demonstrable evidence of homologous agglutination.

It is appreciated that there may be considerable difficulty in interpreting the results of bacteriological examination of the 
TABLE VIII.-Summary of Reports of Cot Deaths in Which Results of Bacteriological Findings are given

\begin{tabular}{|c|c|c|c|c|}
\hline Author & $\begin{array}{l}\text { No. of } \\
\text { Cases }\end{array}$ & $\begin{array}{l}\text { Patho- } \\
\text { gens } \\
\text { Present } \\
\text { in }\end{array}$ & Remarks & $\begin{array}{c}\text { Organs } \\
\text { Examined }\end{array}$ \\
\hline Werne and Garrow (1953) & 24 & $58 \%$ & $\begin{array}{l}\text { Only staphylo- } \\
\text { coccus and } \\
\text { streptococcus } \\
\text { recorded }\end{array}$ & Various \\
\hline Stowens (1957) .. & 116 & $6 \%$ & $\begin{array}{l}\text { Upper respira- } \\
\text { tory and gastro- } \\
\text { intestinal tract } \\
\text { symptoms ex- } \\
\text { cluded. Patho- } \\
\text { logical condi- } \\
\text { tions included }\end{array}$ & Lung; blood \\
\hline Banks (1958) & 66 & $7 \%$ & Pathological con- & Lung \\
\hline Coe and Hartman (1960) & 19 & $16 \%$ & Pathological con:- & Lung; blood \\
\hline Present series $\ldots$ & 55 & $67 \%$ & $\begin{array}{l}\text { Pathological con- } \\
\text { ditions excluded }\end{array}$ & $\begin{array}{l}\text { Lower respiratory } \\
\text { tract; middle } \\
\text { ears; stomach }\end{array}$ \\
\hline
\end{tabular}

respiratory tract, particularly when the material is taken at post-mortem examination. While the nasopharynx has been extensively studied, relatively few investigations have been made on the bacteriology of the lower respiratory tract. It is known, however, that in normal health the trachea and bronchi contain few, if any, bacteria and that, when present, they are usually eliminated rapidly (Wilson and Miles, 1964). Furthermore, the normal host-parasite equilibrium can be easily upset by factors debilitating to the host or indeed by factors altering the balance between the various colonizing bacteria. It was partly for this reason that in this study all cases of cot death in which a demonstrable pathological lesion was found were excluded, as it was felt that invasion of the lower respiratory tract by pathogens may well have been a terminal phenomenon in these cases.

There may be several reasons why the proportion of pathogens isolated from the lungs in this series is so much higher than in previous reports. The post-mortem examinations were carried out as soon after death as was possible, and where some delay was inevitable the bodies were always refrigerated within a few hours of the presumed time of death. More important perhaps is the fact that in the great majority of instances the swabs were cultured within half an hour, and always within two hours, of collection.

The results of this study, in particular the bacteriological findings, are believed to support the view that a high proportion of true cot deaths are the result of fulminating infection of the lower respiratory tract.

The "observed deaths" which occurred in the course of the present study are reported here as it is believed that they have some bearing on infection as a cause of cot death. They are similar to the cot deaths in season, age, prior symptomatology, and bacteriology. They differ only in that the children became suddenly ill when awake, and died under observation at home, on the way to hospital, or on admission to hospital, and were sometimes kept alive by treatment slightly longer than they might have been if untended. In many of them the histological changes were identical to those of the cot-death series, but, in a few, foci of purulent bronchitis or early bronchopneumonia were present. Similarly, bronchitis or pneumonia was seen in some infants who were found dead unexpectedly, but, because of the strict criteria used for the term " cot death," were excluded from this series as having a recognizable cause of death.

Thus the same range of changes in the lung can be present in infants who are found dead unexpectedly as in those who suddenly become ill and are observed to die quickly, and it seems reasonable that infection of the lower respiratory tract is common to most, if not all, as the cause of death. Whether the child dies with or without histological evidence of inflammation of the lower respiratory tract will be determined by the rapidity with which death occurs, and this, in turn, will depend on the virulence of the organism and the resistance of the host.

\section{Summary}

A detailed study has been made of 56 infants found dead unexpectedly and in whom no pathological cause was ascertained.

Pathogens were isolated from the lower respiratory tract in $37(67 \%)$ of the 55 examined bacteriologically.

Similar histological and bacteriological findings were made in 12 infants who were observed to die after a sudden brief illness.

No difference was found between the serum milk antibody titres in cases of cot death and in normal live infants of the same age, and no virus was isolated.

The results of the study are believed to support the view that a high proportion of cot deaths are due to fulminating infection of the lower respiratory tract.

We are indebted to Mr. E. J. Chapman, Mr. H. A. Howden, and Mr. B. A. Sharpley, H.M. Coroners for the County Borough of Grimsby, and for the Caistor and Louth Districts of Lincolnshire, respectively, for permission to publish details of the cases ; and to Dr. E. H. Gillespie and Dr. M. A. Wilson, Public Health Laboratory, Sheffield, who carried out the virus cultures and the phage-typing for this study.

\section{REFERENCES}

Banks, A. L. (1958). Mth. Bull. Minist. Hlth Lab. Serv., 17, 182.

Boyden, S. V. (1951). f. exp. Med., 93, 107

Coe, J. I., and Hartman, E. E. (1960). F. Pediat., 56, 786.

- and Peterson, R. D. A. (1963). 7. Lab. clin. Med., 62, 477.

Emery, J. L., and Crowley, E. M. (1956). Brit. med. F., 2, 1518.

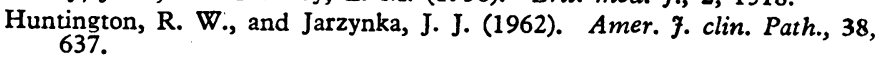

Gold, E., Adelson, L., and Godek, G. K. (1964). Pediatrics, 33, 541. Gunther, M., Aschaffenburg, R., Matthews, R. H., Parish, W. E., and
Coombs, R. R. A. (1960). Immunology, 3, 296.

Parish, W. E., Barrett, A. M., and Coombs, R. R. A. (1960a). Ibid., 3 307.

- Gunther, M., and Camps, F. E. (1960b). Lancet, 2, 1106. Richards, C. B., France, N. E., and Coombs, R. R. A. (1964). Int. Arch. Allergy, 24, 215.

Peterson, R. D. A., and Good, R. A. (1963). Pediatrics, 31, 209.

Stowens, D. (1957). Amer. F. Dis. Child., 94, 674.

- (1958). Postgrad. Med., 23, A-52.

Werne, J., and Garrow, I. (1953). Amer. F. Path., 29, 633.

Wilson, G. S., and Miles, A. A. (1964). Topley and Wilson's Principles of Bacteriology and Immunity, 5th ed., chap. 44 and 89. Arnold, 